\title{
Sosyal Bilgiler Öğretmen Adaylarının Siber Zorbalık Düzeylerinin İncelenmesi
}

\author{
Baysal GÜNGÖR ${ }^{1}$ \\ Eda TINGIŞ̧² \\ Ayşe Beril SAROL ${ }^{3}$
}

\begin{tabular}{|c|c|}
\hline Makale Bilgisi & Özet \\
\hline $\begin{array}{c}\text { Alınma Tarihi } \\
\text { 16.11.2020 } \\
\text { Kabul Tarihi } \\
\text { 30.12.2020 } \\
\text { Yayınlanma Tarihi } \\
\text { 30.12.2020 }\end{array}$ & $\begin{array}{l}\text { Bu araştırmanın amacı Sosyal Bilgiler öğretmen adaylarının siber zorbalık } \\
\text { düzeylerinin cinsiyet, yaş, ekonomik durum, internette geçirdikleri süreye } \\
\text { göre incelenmesidir. Çalışma 2019-2020 eğitim-öğretim yılında Akdeniz } \\
\text { Üniversitesi sosyal bilgiler eğitimi anabilim dalında öğrenim gören } 115 \\
\text { öğretmen adayı ile gerçekleştirilmiştir. Araştırmaya katılan öğretmen } \\
\text { adaylarından 55'i (\%47,8) erkek, } 60^{\prime} ı \text { (\%52,2) kadındır. Araştırmada veri } \\
\text { toplama aracı olarak "Siber Zorbalık Ölçeği" kullanılmıştır. Araştırmada } \\
\text { nicel araştırma yöntemlerinden tarama modeli kullanılmıştır. Sosyal bilgiler } \\
\text { öğretmen adaylarının kendilerine uygulanan "Siber Zorbalık Ölçeğine" } \\
\text { verdikleri cevaplar SPSS üzerine işlenmiştir. Verilerin analizinde ilişkisiz } \\
\text { örneklemler t-testi ve tekyönlü varyans analizi (ANOVA) kullanılmıştır. } \\
\text { Araştırma sonucunda; Sosyal Bilgiler öğretmen adaylarının siber zorbalık } \\
\text { düzeyleri, cinsiyet ve yaş değişkenine göre anlamlı bir farklılık göstermezken } \\
\text { internette geçirilen süre ve ekonomik durum değişkenine göre anlamlı } \\
\text { düzeyde farklılaştığı sonucuna ulaşılmıştır. }\end{array}$ \\
\hline
\end{tabular}

\footnotetext{
${ }^{1}$ Yüksek Lisans Öğrencisi Akdeniz Üniversitesi Eğitim Bilimleri Enstitüsü, Türkiye. baysalgungor@hotmail.com ORCID: 0000-0001-8056-6124

${ }^{2}$ Yüksek Lisans Öğrencisi Akdeniz Üniversitesi Eğitim Bilimleri Enstitüsü, Türkiye. eda.tngs95@gmail.com ORCID:000-0001-7242-0010

${ }^{3}$ Yüksek Lisans Öğrencisi Akdeniz Üniversitesi Eğitim Bilimleri Enstitüsü, Türkiye. berilsarol.2014@gmail.com ORCID:000-0003-3171-1668
} 


\section{Investigation of Cyber Bullying Levels of Social Studies Teacher Candidates}

\section{Article Info Abstract}

The aim of this study is to examine the cyberbullying levels of Social Studies teacher candidates according to their gender, age, economic status, and those on the internet. The study was carried out with 115 teacher candidates studying at Akdeniz University, Department of Social Studies Education, in the 20192020 academic year. Of the teacher candidates participating in the study, 55 $(47.8 \%)$ are male and 60 (52.2\%) are female. "Cyber Bullying Scale" was used as Received a data collection tool in the study. In the research, scanning model, one of the 16.11.2020 quantitative research methods, was used. The burden of social studies teacher candidates' answers to the "Cyber Bullying Scale" was processed on SPSS.

Accepted Unrelated samples t-test and one-way analysis of variance (ANOVA) were 30.12.2020 used to analyze the data. About the research; It was concluded that the rates of

Published Online 30.12.2020 cyber bullying of social studies teacher candidates did not show a significant difference according to gender and age variables, but they differ according to the variables of time spent on the internet and economic situation.

Keywords: Social Studies, Bullying, Cyber Bullying, Cyber Bully, Cyber Victim 


\section{GíRIŞ}

21. yüzyıl teknoloji, değişim ve gelişim çağı olarak bilinmektedir. Geliştirilen ve bulunan birçok kitle iletişim araçları insan yaşamını kolaylaştırmasının yanında bu teknolojik gelişmelerin eğitim ve öğretime sağladığı faydaları görmekteyiz. Bilgi teknolojilerinin hızlı gelişimi, her alanı olduğu gibi eğitimi de etkilemektedir. Eğitimde değişim ve gelişme, bilgi teknolojileri ile bağlantılı olarak görülebilir. Bilgi teknolojileri, daha geniş bir yelpazede öğrenme ve öğretme süreçlerini bir işlevle birlikte sağlayan araçların yanı sıra, bireylerin farklı yerlerde kişisel kullanımı ve iletişimini sağlayan araçlardan oluşur (Topkaya, Tangülü, Yılar ve Şimşek, 2015).

Birçok araştırmada, kişisel bilgisayar kullanımının her yaşta ve düzeyde olduğu bilinmektedir. Bu yaygın kullanımların ve teknolojinin hızla gelişmesi ve yaygınlaşması olumlu etkiler doğurduğu gibi olumsuz etkiler de yaratmıştır. Bilgi teknolojilerinin çokça kullanılması bazı etik problemleri de beraberinde getirmektedir. Teknoloji alanındaki değişimler ve teknolojinin gençler tarafından daha yaygın kullanılmaya başlanması, okullarda öğrencilerin göstermiş olduğu zorbalık davranışlarının teknolojiyi kullanarak dijital yansıması olarak karşımıza çıkmaktadır. Bilgi ve iletişim teknolojilerinin kötü niyetli kullanımı okullarda öğrenciler arasında yaşanan zorbalık türleri arasında "siber zorbalık" (cyber bullying) adı verilen yeni bir zorbalık türünün çıkmasına neden olmuştur. Siber zorbalık, bilgisayar, cep telefonu ve diğer iletişim teknolojileri aracılığıyla bir birey ya da gruba karşı yapılan kasıtlı ve tekrarlanan teknik ya da ilişkisel tarzda zarar verme davranışlarının tümüdür (Arıcak, 2011; Belsey, 2007; Hinduja ve Patching, 2009; Li, 2006; Yaman, Eroğlu ve Peker, 2011).

Pişkin (2002) zorbalığı, bir ya da birden fazla öğrencinin kendilerinden daha güçsüz öğrencileri bilinçli ve sürekli bir şekilde rahatsız etmesiyle sonuçlanan ve rahatsız edilenin kendisini koruyamayacak vaziyette bulunduğu bir saldırganlık çeşidi şeklinde ifade etmiştir.

Pişkin (2002), zorbalığın meydana geliş şekillerini şu şekilde açıklamıştır:

- Darp etmek,

- Tokat veyahut tekme atmak,

- Çekmek, itmek veya dürtmek,

- Yildırmak, ürkütmek.

- Alay etmek, sinir etmek, dikkate almamak,

- Aşağılayıcı isimler takmak,

- Mağdur kişiye veya ailesine hakaret etmek,

- Mağdur olan kişi hakkında asılsız söylemler yaymak,

- Mağdur olan kişi hakkında onur kırıcı yazılar kaleme almak,

- Mağdur olan bireyi dişlamak veya sosyal guruplardan atmak,

- Mağdur olan bireyi tehdit etmek veya mağdurun eşyalarına zarar vermek. 
Bir dizi çalışma (Watson ve ark., 2010) zorbalık davranışının altı ana rol içerdiğini belirlemiştir: Zorba, mağdur, zorba yardımcısı, zorba destekçisi, savunmacı ve seyirci koruyucusu ve seyirci/seyirci. Saf zorba ve saf mağdur, zorba mağdur senaryosundaki orijinal karakterlerdir. Kendinden daha güçsüz birey ya da bireylere ardışıklı bir şekilde zarar verme kastıyla saldırıda bulunan kişilere zorba; zorbalığa maruz kalan kişiye de mağdur adı verilmektedir (Burnukara ve Uçanak, 2012).

Yılmaz (2016), zorbalık türlerini şu şekilde açıklamıştır:

1. Fiziksel Zorbalık: Vurma, dürtme, boğazlama, saç çekme tarzındaki eylemlerdir.

2. Sözel Zorbalık: Üzücü isimler takma, alay etme ve dedikodu yapma gibi eylemlerdir.

3. Duygusal Zorbalık: Şantaj, adını çıkarma, aşağılama, dil, din, ırk gibi özellikleri aşağılama ve dışlama gibi eylemlerdir.

4. Cinsel Zorbalık: Teşhircilik, röntgencilik, cinsel taciz, saldırı ve istismar türündeki eylemlerdir.

5. Siber Zorbalık: Facebook, Twitter, Skype gibi sosyal medyanın yaygınlaşmasıyla ortaya çıkan bir zorbalık çeşididir. İnternet yoluyla ve mesaj vasıtasıyla rahatsız etmek, aşağılamak ve dedikodu yapmak siber zorbalık eylemleri içerisinde yer almaktadır (Korkmaz, 2016).

\section{Siber Zorbalık}

İnternet, ergenler için bazı durumlarda bir kaçış ve kendini rahat ifade etme ortamına dönüşebilmekte; ergenlerin çevreleri ile yaşadıkları iletişim problemlerini, akademik başarısızlıktan doğan sıkıntılarını ve benzer problemlerini unutmak ya da diğer insanlarla rahatlıkla paylaşabildikleri bir yer haline gelebilmektedir (Taçyıldız, 2010). Gerçek yaşamda var olan ego sınırlamasının sanal ortamda büyük ölçüde ortadan kalkmasıyla kişiler gerçek yaşamda yapamayacakları davranış ve söylemleri rahatça sergileyebilmektedirler (Sayar, 2002). Son yıllarda teknolojinin hılı gelişimi sonucu, bilgisayarlar ve cep telefonları gibi yeni teknolojiler okullara ve öğrencilere kadar ulaştı. Birçok önemli araştırma bilgisayarların öğrenmenin tüm konularına olumlu etkileri olduğunu göstermiştir. Ancak sınıflara giren elektronik iletişim araçları aynı zamanda dikkat çekici sorunları da beraberinde getirmektedir (Li, 2006).

Literatürde tanımlanan siber zorbalık kavramları incelendiğinde bir davranışın siber zorbalık sayılabilmesi için "zarar verme bilinci" ve "tekrar" koşullarının sağlanması gerektiğini vurgulamıştır (Arıcak, 2015). Sosyal medya ortamlarının dünya genelinde çocuklar ve gençler tarafından hızla kabul görmesinin temelinde onlara; kendini temsil etme, öğrenme, ilişki ağları kurup geliştirme, samimi ilişkileri ve kişisel mahremiyeti koruyup yönetme gibi temel birtakım konularda dikkate değer yeni imkanlar sunduğu iddia edilmektedir. Bununla birlikte yukarıda değinilen pozitif getirileriyle birlikte sanal ortam sınırları tahmin edilemeyecek tehlikeleri içermektedir. Bu tehlikelerin başında adına siber zorbalık dediğimiz kavram gelmektedir. 
Türkiye' de siber zorbalıkla ilgili yapılan araştırmalara göre, ergenlerin en çok karşılaştığı siber zorbalık davranışlarının küfür, hakaret ve tehdit içerikli ifadelerin kullanımı (Aslan ve Doğan, 2017; Kestel ve Akbıyık, 2016), çevrim içi sohbet ortamını ya da oyunu terk etmeye zorlama, bilgi ve iletişim teknolojileri yoluyla alaya alma (Tamer ve Vatanartıran, 2014) olduğu sonuçları elde edilmektedir. Eroğlu ve Peker (2015), tarafından yapılan araştırmada, bireylerin siber zorbalık statüleri (siber zorba/ siber mağdur/ zorba-mağdur) ile akran ilişkileri arasındaki ilişki incelenmiş, akran ilişkilerinin siber zorbalık statülerini yordadığı sonucuna ulaşılmıştır. Bu doğrultuda bireyin arkadaşlarının onayını almak istemesi, onları desteklemesi ya da onların kışkırtmalarına engel olamaması sonucunda, siber zorbalık davranışı sergileyebileceği yorumu yapılmıştır.

\section{Siber Zorbalık Araçları}

Literatürde konu ile ilgili araştırmalar incelendiğinde siber zorbaların kullandıkları araçların çeşitli başlıklar altında ele alındığı görülmektedir (Bhat, 2008; Hinduja ve Patchin, 2008; Kowalski vd., 2008, s.51-57; Price ve Dalgleish, 2010; Rogers, 2010, s. 14-16; Shariff ve Gouin, 2005; Smith vd., 2008; Willard, 2007, s.20-26; Ybarra, Mitchell, Wolak ve Finkelhol, 2006).

- Anlık Mesajlaşma

- Cep Telefonu

- E-posta

- Metin mesajları

- Sosyal Paylaşım Siteleri

- Sohbet Odalar1

- Bloglar

- Web Siteleri

- Çevrimiçi Oyunlar

- Forumlar

\section{Siber Zorbalığın Görülme Biçimleri}

Siber zorbalığın içerdiği davranışlar Willard (2006) tarafından şu şekilde belirlenmiştir; "kızdırmak, rahatsız etmek, kötülemek, taklit etmek, dışlamak, kandırmak ve takipçi tacizlik" olmak üzere yedi adet davranış türünden bahsedilmiştir

- Kızdırma (Online Kavga): Kızgın, kabaca mesajlar gönderme,

- Rahatsız etme: Sürekli olarak can sıkıcı mesajlar gönderme,

- Takipçi tacizlik (Siber Taciz): Tekrar eder nitelikte taciz, zararlı, tehdit içeren veya korku vermeye yönelik cep telefonu veya internet aracılığı ile mesaj, e-mail gönderme

- Kötüleme: Gerçeğe aykırı bir şekilde veya ilişkileri bozmak üzere e-mail gönderme,

- Taklit Etme: Kişiyi kötü duruma düşürmek, utandırmak, itibarını zedelemek için onun yerine geçmek, onu taklit etmek veya bilgilerini kullanarak mesajlar gönderme, forumlarda ya da sosyal paylaşım sitelerinde yorumlar yapma,

- Kandırma: Birini kandırarak kişisel bilgilerini ele geçirme ve sosyal mühendislik yapma, 
- Dışlama: Bilerek çevrimiçi bir gruptan atma veya iletişim kurmasını engelleme, dışlama gibi davranışlar sergiledikleri belirlenmiştir. Ayrıca Nocentini vd. (2010)' de siber zorbalık davranışlarını aşağıdaki şekilde sınıflandırmışlardır; Nocentini vd. (2010) siber zorbalık davranışlarını;

- Yazılı ve sözlü davranışlar (telefon çağrıları, mesajlaşma, e-mail, anlık mesajlaşma, chat odaları, blog siteler, sosyal paylaşım siteleri ve web sayfaları),

- Görsel davranışlar (internet ya da cep telefonu kullanarak resim ya da video paylaşma, gönderme),

- Dışlama (bilerek kişiyi çevrimiçi bir gruptan dışlama),

- Taklit etme (kişisel bilgileri çalmak veya ifşa etmek, başka birinin ismini ve hesabını kullanmak) olarak sınıflandırmıştır. Bu davranışlar en sık görülen siber zorbalık davranış biçimleridir.

\section{Siber Zorbalığın Mağdur Üzerindeki Etkileri}

Siber mağdur olan bireylerin kişilik özellikleri göz önüne alındığında, siber mağdurların içe dönük, sessiz, sakin ya da fazla dişa dönük, popüler, güvenli internet kullanım bilgilerine sahip olmayan veya bunları uygulamayan, herhangi bir engeli ya da eksikliği olan bireyler olduğu görülmektedir.

Siber zorbalığın tesirlerinin genellikle mağdurlar üzerinde görüldüğü anlaşılmaktadır. Türkiye ve diğer ülkelerde yapılan bilimsel çalışmalarda, siber mağduriyetin bireyler üzerinde çeşitli etkilere yol açtığı sonuçları elde edilmiştir. Araştırmalara göre, siber mağduriyet bireyde stres (Morin ve ark., 2018; Ybarra, Mitchell, Wolak ve Finkelhor, 2006), kayg1 (Chu ve ark., 2018), korku, çaresizlik, değersizlik, yalnızlık (Olenik-Shemesh, Heiman ve Eden, 2012; Spears, Slee, Owens ve Johnson, 2009; Şahin, 2012), kendini güvende hissetmeme (Arıcak ve ark., 2008), öfke, tedirginlik (Kestel ve Akbıyık, 2016), sosyal geri çekilme (Coelho ve Romao, 2018), umutsuzluk (Raskauskas ve Stoltz, 2007), depresyon (Ayas, 2014), intihar düşünceleri (Patchin ve Hinduja, 2010), intikam düşünceleri (Yaman ve Peker, 2012) vb. psikolojik ve sosyal etkilere yol açmaktadır. Siber zorbalığın mağdur üzerindeki etkilerinin boyutu; maruz kalınan siber zorbalık türünün yoğunluğuna, süresine, mağdurun psikolojik durumuna ve siber zorbalığın sebep olduğu strese yönelik ortaya koydukları dirence göre değişebilmektedir (Sleglova ve Cerna, 2011).

\section{YÖNTEM}

\section{Araştırma modeli}

$\mathrm{Bu}$ araştırmada nicel araştırma modellerinden tarama modeli kullanılmıştır. Bu araştırmada nicel araştırma modellerinden tarama modeli kullanılmıştır. Tarama modeli bir konu ya da olayla ilgili katılımcıların düşüncelerinin veya ilgi, beceri, yetenek tutum vb. niteliklerinin ortaya çıkarıldığı, genellikle de nispeten büyük bir örneklem üzerinde yapılan araştırmalar olup değişkenler arasındaki ilişkilerin incelendiği bir araştırma modelidir (Büyüköztürk, 
Çakmak, Akgün, Karadeniz ve Demirel, 2012, s.177; Demirkaya ve Çakar, 2012; Demirkaya ve Ünal, 2018; Karasar, 2009, s.77; Öztürk ve Aç1l, 2020).

\section{Evren ve Örneklem}

Araştırmanın evrenini Türkiye'de sosyal bilgiler öğretmenliği anabilim dalında öğrenim gören öğretmen adayları oluşturmaktadır. Araştırmanın örneklemini ise 2019-2020 eğitimöğretim yılı güz döneminde Akdeniz Üniversitesi eğitim fakültesinde öğrenim gören 115 sosyal bilgiler öğretmen adayı oluşturmaktadır. Örneklem seçiminde kolay/uygun örnekleme yöntemi kullanılmıştır. Bu tür örneklemede araştırmacı kendisine yakın olan ve erişebilirliğinin kolay olduğu durumu tercih eder (Yurdakul, 2013, s.83). Araştırmaya katılan öğretmen adaylarından 55 i (\%47.8) erkek, 60 1 (\%52.2) kadındır.

\section{Veri toplama arac1}

Siber Zorbalık Ölçeği, Arıcak, Kınay ve Tanrıkulu (2012) tarafından siber zorbalık davranışlarını ölçmek amacıyla geliştirilmiştir. Ölçek geliştirme çalışması 11- 18 yaş arası 515 ergenin katılımıyla gerçekleştirilmiştir. Tüm maddeler için temel bileşenler analizi bağlamında açıklayıcı faktör analizi gerçekleştirilmiştir. KaiserMeyer-Olkin örneklem uygunluğu değeri .939 ve Bartlett Sphericity Testi yaklaşık Ki 28 Kare değeri 9197.54 (p<.05) olarak bulunmuştur. Bileşen Matrisi incelendiğinde tüm maddelerin tek faktör altında toplandığı görülmüştür. Bu tek faktör 12.139'luk bir özdeğer ile toplam varyansın \%50.58'ini açıklamaktadır. Aynı zamanda çizgi grafiği (screeplot) üzerinde kırılma noktası incelenmiş, kırılma noktasından da ölçeğin tek faktörlü bir yapı gösterdiği görülmüştür. Tek faktör altındaki maddelerin faktör yükleri .49 ile .82 arasında değişmektedir.Cronbach alfa katsayısı .95 olup; test-tekrar test güvenirlik katsayısı ise .70 olarak bulunmuştur. Elde edilen bu değerler, ölçeğin güvenilir bir ölçme aracı olduğu şeklinde yorumlanabilmektedir (Arıcak, Kınay ve Tanrıkulu, 2012). Ölçek,21 maddeden oluşmakta olup dörtlü (Hiçbir Zaman, Bazen, Çoğu Zaman, Her Zaman) skala üzerinden yanıtlanmaktadır. "Hiçbir Zaman" bir puan olarak, "Her Zaman" yanıtı ise dört puan olarak değerlendirilmektedir. Böylece ölçekten alınabilecek en düşük puan 24, en yüksek puan ise 96 olmaktadır. Ölçekten alınan toplam puanın yüksek olması katılımcının siber zorbalık davranışının yüksek olduğunu göstermektedir (Arıcak, Kinay ve Tanrikulu 2012).

\section{Verilerin analizi}

Çalışmaya katılan Sosyal Bilgiler öğretmen adaylarının kendilerine uygulanan "Siber Zorbalık Ölçeği"ne verdikleri cevaplar SPSS 23.0 üzerinde oluşturulan veri tabanına işlenmiştir. Verilerin analizinde ilişkisiz örneklemler t-testi ve tekyönlü varyans analizi (ANOVA) kullanılmıştır.

\section{BULGULAR}

$\mathrm{Bu}$ bölümde araştırma sürecinde elde edilen verilerin analiz edilmesi sonucu ulaşılan bulgulara ve bu bulgulara ilişkin yorumlara yer verilmiştir. 


\section{Birinci alt probleme ilişkin bulgular}

“Cinsiyet değişkenine göre sosyal bilgiler öğretmen adaylarının siber zorbalık düzeyleri arasında anlamlı bir farklılık var mıdır?" alt problemini çözümlemek amacıyla t-testi yapılmıştır. Elde edilen bulgular aşağıdaki tablolarda verilmiştir.

\section{Tablo 1.}

Sosyal Bilgiler Öğretmen Adaylarının Siber Zorbalık Ölçeği Ortalama Puanlarının Cinsiyet Değişkenine Göre T-Testi Sonuçları

\begin{tabular}{|c|c|c|c|c|c|c|}
\hline Cinsiyet & $\mathbf{N}$ & $\bar{x}$ & $S$ & SD & $T$ & $\mathbf{P}$ \\
\hline Erkek & 55 & 0541 & 00980 & \multirow[t]{2}{*}{113} & \multirow[t]{2}{*}{ 725 } & \multirow[t]{2}{*}{,470 } \\
\hline Kadın & 60 & ,0524 & ,01528 & & & \\
\hline
\end{tabular}

Tablo 1 incelendiğinde sosyal bilgiler öğretmen adaylarının siber zorbalık ölçeği ortalama puanlarının cinsiyet değişkenine göre anlamlı bir farklılık göstermediği görülmektedir, $\mathrm{t}_{(113)}=$ ,725, p>0.05. Erkek sosyal bilgiler öğretmen adaylarının siber zorbalık ölçeği ortalama puanları $(X=, 0541)$, kadın öğretmen adaylarına göre $(X=, 0524)$ yüksek olmasına rağmen istatistiksel anlamda anlamlı bir farklılık değildir.

\section{İkinci alt probleme ilişkin bulgular}

“Yaş değişkenine göre sosyal bilgiler öğretmen adaylarının siber zorbalık düzeyleri arasında anlamlı bir farklılık var mıdır? " alt problemini yanıtlamak amacıyla tek yönlü varyans analizi (ANOVA) yapılmıştır. Elde edilen bulgular aşağıdaki tablolarda verilmiştir.

\section{Tablo 2.}

Sosyal Bilgiler Öğretmen Adaylarının Siber Zorbalık Ölçeği Ortalama Puanları İle Yaş Düzeylerinin Betimsel İstatistikleri

\begin{tabular}{llll}
\hline & $\mathbf{N}$ & $\overline{\mathbf{x}}$ & SS \\
\hline $18-20$ yas & 18 &, 0511 &, 00656 \\
$21-23$ yas & 77 &, 0543 &, 01485 \\
$24+$ yas & 20 &, 0510 &, 00824 \\
Total & 115 &, 0532 &, 01293 \\
\hline
\end{tabular}

\section{Tablo 3.}

Sosyal Bilgiler Öğretmen Adaylarının Siber Zorbalık Ölçeği Ortalama Puanlarının Yaş Değişkenine Göre Anova Sonuçları

\begin{tabular}{lccccc}
\hline & KT & SD & KO & F & P \\
\hline Grup İçi &, 000 & 2 &, 000 &, 774 &, 463 \\
Grup Diş1 &, 019 & 112 &, 000 & & \\
Toplam &, 019 & 114 & & & \\
\hline
\end{tabular}

Tablo 2 ve 3 analiz sonuçlarına göre sosyal bilgiler öğretmen adaylarını siber zorbalık ölçeği ortalamaları ile yaş değişkeni arasında anlamlı bir farklılığın olmadığı görülmektedir, $\mathrm{F}_{(2,}$ ${ }_{112}=, 774, \mathrm{p}<0,05$. Yapılan Scheffe testinin sonuçlarına göre, 21-23 yaş aralığında olan sosyal 
bilgiler öğretmen adaylarının siber zorbalık ölçeği ortalama puanlarının diğer yaş gruplarına daha yüksek olduğu görülse de bu sonuç istatistiksel anlamda anlamlı bir farklılık oluşturmamaktadır.

\section{Üçüncü alt probleme ilişkin bulgular}

"Sosyal bilgiler öğretmen adaylarının ekonomik durumları ile siber zorbalık düzeyleri arasında anlamlı bir fark var mıdır?" alt problemini çözümlemek amacıyla tek yönlü varyans analizi (ANOVA) yapılmıştır. Elde edilen bulgular aşağıdaki tablolarda verilmiştir.

\section{Sosyal Bilgiler Öğretmen Adaylarının Siber Zorbalık Ölçeği Ortalama Puanlarının Ekonomik Durum Değişkenine Göre ANOVA Sonuçları}

Tablo 4.

Sosyal Bilgiler Öğretmen Adaylarının Siber Zorbalık Ölçeği Ortalama Puanları İle Ekonomik Durumlarının Betimsel İstatistikleri

\begin{tabular}{llll}
\hline & $\mathbf{N}$ & $\mathbf{X}$ & SS \\
\hline Alt & 7 &, 0534 &, 00598 \\
Ortanin Altı & 14 &, 0509 &, 00364 \\
Orta & 75 &, 0525 &, 00881 \\
Ortanin Üstü & 16 &, 0524 &, 01040 \\
Üst & 3 &, 0862 &, 06288 \\
\hline Toplam & 115 &, 0532 &, 01293 \\
\hline
\end{tabular}

\section{Tablo 5 .}

Sosyal Bilgiler Öğretmen Adaylarının Siber Zorbalık Ölçeği Ortalama Puanlarının Ekonomik Durumlarına Göre Anova Sonuçları

\begin{tabular}{lcccccc}
\hline & KT & SD & KO & F & P & Anlamlı Farklılı \\
\hline Gruplar arası & & & & & & $\begin{array}{c}\text { Alt-Üst, Ortanın Altı - } \\
\text {,003 }\end{array}$ \\
& 4 &, 001 & 5,943 &, 000 & $\begin{array}{c}\text { Üst, Orta-Üst, Ortanın } \\
\text { üstü - Üst }\end{array}$ \\
\hline Gruplar içi &, 016 & 110 &, 000 & & & \\
\hline Toplam &, 019 & 114 & & & & \\
\hline
\end{tabular}

Tablo 4 ve 5 incelendiğinde sosyal bilgiler öğretmen adaylarının siber zorbalık ölçeği ortalamaları ile ekonomik durumları arasında anlamlı bir farklılığın olduğu görülmektedir, $\mathrm{F}_{(4,110)}=5,943, \mathrm{p}<0,05$. Bu farklılığın hangi düzeylerde olduğunu bulmak amaciyla yapılan Scheffe testinin sonuçlarına göre, alt $(X=, 0534)$, ortanın altı $(X=, 0509)$, orta $(X=, 0525)$, ortanın üstü $(X=, 0524)$ ile üst $(X=, 0862)$ ekonomik düzey arasında olduğu sonucuna ulaşılmıştır. Bu durum sosyal bilgiler öğretmen adaylarının ekonomik düzeyleri arttığında siber zorbalık düzeylerinin de arttığını göstermektedir. Tablo 5' de hesaplanan kt değeri ,003/,019=0,15'dir. Buna göre siber zorbalık ölçeği ortalama puanlarında gözlenen varyansın yaklaşık \%15'nin ekonomik düzeye bağlı olduğu söylenebilir. 


\section{Dördüncü alt probleme ilişkin bulgular}

"Sosyal bilgiler öğretmen adaylarının internette geçirdikleri süre ile siber zorbalık düzeyleri arasında anlamlı bir fark var mıdır?" alt problemini çözümlemek amacıyla tek yönlü varyans analizi (ANOVA) yapılmıştır.

\section{Öğretmen Adaylarının Siber Zorbalık Ölçeği Ortalama Puanlarının İnternette Geçirdikleri Sürelere Göre ANOVA Sonuçları}

\section{Tablo 6 .}

Sosyal Bilgiler Öğretmen Adaylarının Siber Zorbalık Ölçeğgi Ortalama Puanlar ile İnternette Geçirdikleri Sürelerin Betimsel İstatistikleri

\begin{tabular}{llll}
\hline & $\mathbf{N}$ & $\mathbf{X}$ & SS \\
\hline 0-3 saat & 42 &, 0512 &, 00591 \\
3-6 saat & 46 &, 0512 &, 00877 \\
6+ saat & 27 &, 0598 &, 02204 \\
\hline
\end{tabular}

\section{Tablo 7.}

Sosyal Bilgiler Öğretmen Adaylarının Siber Zorbalık Ölçeği Ortalama Puanlarının İnternette Geçirdikleri Süreye Göre Anova Sonuçları

\begin{tabular}{lcccccc}
\hline & KT & SD & KO & F & P & Anlamlı Farkl1lık \\
\hline Gruplar arası &, 002 & 2 &, 001 & 4,879 &, 009 & $0,3-6+$ ve 3,6-6+ \\
\hline Gruplar içi &, 018 & 112 &, 000 & & & \\
\hline Toplam &, 019 & 114 & & & & \\
\hline
\end{tabular}

Tablo 6 ve 7 incelendiğinde sosyal bilgiler öğretmen adaylarının siber zorbalık ölçeği ortalamaları ile internette geçirdikleri süre bakımından anlamlı bir farklılık olduğu görülmektedir, $\mathrm{F}_{(2,112)}=4,879, \mathrm{p}<0,05$. Bir başka ifadeyle internette geçirilen süre arttıkça siber zorbalık düzeylerinin arttığı görülmüştür. Bu farklılığın hangi süreler içerisinde olduğunu bulmak amacıyla yapılan Scheffe testinin sonuçlarına göre, internette $0-3$ saat $(X=, 0512)$ ile 3-6 saat $(X=, 0512)$ arası zaman geçiren sosyal bilgiler öğretmen adaylarının neredeyse aynı düzeyde olduğu ancak 6 saat ve üzeri $(X=, 0598)$ zaman geçiren öğretmen adaylarının anlamlı oranda daha yüksek olduğu belirlenmiştir. Tablo 7' de hesaplanan kt değeri ,002/,012=0,10' dur. Buna göre siber zorbalık ölçeği ortalama puanlarında gözlenen varyansın yaklaşı \%10'nun internette geçirilen süreye bağlı olduğu söylenebilir.

\section{SONUÇ, TARTIŞMA ve ÖNERILER}

Sosyal bilgiler öğretmen adaylarının siber zorbalık düzeylerinin incelendiği bu çalışmada cinsiyet ve yaş değişkenlerinin siber zorbalık düzeyini etkilemediği, bunun yanında ekonomik durum ve internette geçirilen sürenin siber zorbalık düzeyi üzerinde etkisinin olabileceği görülmüştür.

Araştırma sonucunda elde edilen bulgulara göre: Siber zorbalık düzeyi cinsiyete göre farklılık göstermemektedir. Erkek sosyal bilgiler öğretmen adaylarının siber zorbalık ölçeği ortalama puanları, kadın öğretmen adaylarına göre yüksek olmasına rağmen istatistiksel anlamda 
anlamlı bir farklılık değildir. Bir diğer analiz sonucuna göre, Sosyal bilgiler öğretmen adaylarının siber zorbalık ölçeği ortalama puanları ile yaş değişkeni arasında anlamlı bir farklılığının olmadığı görülmektedir.

Sosyal bilgiler öğretmen adaylarının siber zorbalık ölçeği ortalamaları ile ekonomik durumları arasında anlamlı bir farklılığın olduğu görülmektedir. Bu farklılığın hangi düzeylerde olduğunu bulmak amacıyla yapılan Scheffe testinin sonuçlarına göre; alt, ortanın altı, orta, ortanın üstü ile üst ekonomik düzey arasında anlamlı farklılık olduğu sonucuna ulaşılmıştır. Bu durum sosyal bilgiler öğretmen adaylarının ekonomik düzeyleri arttığında siber zorbalık düzeylerinin de arttığını göstermektedir. Diğer analiz sonucuna göre, İnternette geçirilen süre arttıkça siber zorbalık düzeylerinin arttığı görülmüştür. Bu farklılığın hangi süreler içerisinde olduğunu bulmak amacıyla yapılan Scheffe testinin sonuçlarına göre, internette 0-3 saat ile 3-6 saat arası zaman geçiren sosyal bilgiler öğretmen adaylarının neredeyse aynı düzeyde olduğu ancak 6 saat ve üzeri zaman geçiren öğretmen adaylarının siber zorbalık düzeylerinin anlamlı oranda daha yüksek olduğu belirlenmiştir. İnternette geçirilen süre arttıkça siber zorba olmanın arttığını ortaya koyan araştırmalar ise (Burnukara, 2009; Çiftçi, 2010; Serin, 2012) bulunmaktadır. Bu çalışmalarda yapılan çalışmamızla çıkan sonuçlarda paralellik göstermektedir.

Siber mağduriyet ile ilgili çalışmalar incelendiğinde benzer ve farklılık arz eden çalışmalar olduğu görülmektedir; cinsiyet açısından bakıldığında erkeklerin kızlara göre daha fazla zorbalık yaptıkları kız öğrencilerin mağdur oldukları tespit edilmiştir. (Dilmaç, 2009; Peker vd., 2012: 211, Serin, 2012, Şahin vd., 2010: Süslü, 2016). Yapılan bu çalışmalarda çıkan sonuçların benzerliğini destekler niteliktedir.

Siber zorbalıkta cinsiyetin etkisini araştıran bilim insanları farklı sonuçlara ulaşmışlardır. Araştırmacıların büyük bir bölümü cinsiyetin siber zorbalıkta belirleyici rol oynamadığını, kız ve erkeklerin benzer sıklıkta kurban ve zorba rollerinde olduklarını ifade etmişlerdir (Patchin ve Hinduja, 2006; Slonje ve Smith, 2008; Smith vd, 2008; Topçu vd., 2008; Williams ve Guerra, 2007). Diğer araştırmacılar ise cinsiyet farklılığının belirleyici olduğu sonucuna ulaşmışlardır (Arıcak vd., 2008; Kowalski ve Limber, 2007; Li, 2007). Cinsiyet farklılığının önemine değinen araştırma sonuçlarında kızların erkeklere göre daha fazla kurban rolünde oldukları dikkat çekmektedir.

Araştırma sonucunda elde edilen bulgulara göre şu öneriler verilmiştir:

- Sosyal Bilgiler öğretmen adaylarına lisans eğitiminde siber zorbalığın psikolojik boyutları hakkında derslere konu olabilir ve hem öğretmen adayının hem de öğrenciler üzerinde siber zorbalığın psikolojik etkilerinde farkındalıklar oluşturulacak etkinlikler ve eğitimler düzenlenebilir.

- Medya okuryazarlığı ve doğru sosyal medya kullanımı ve sosyal medya uygulamaları hakkında detaylı bilgilendirmeler yaparak ilk önce öğretmen adaylarında daha sonra öğrencilerini bilinçlendirebilir. 
- Sosyal Bilgiler öğretmen adaylarında ve şu an görev yapan öğretmenlere yönelik siber zorbalık hakkında içerik çeşitlendirilerek farklı çalışmalar yapılabilir.

- Ekonomik gelirin siber zorbalıkta etkili olduğunu göz önüne alırsak bu alanda zorbalık yapma eğilimi içerisinde olan gruba yönelik bilinçlendirme amaçlı çalışmalar yapılabilir.

- Öğretmen adayları mesleğe başlamadan önce çalışacakları kurumda öğrencilerinin siber zorbalığa maruz kalma durumlarında iletişime geçecekleri ve onlara pedagojik olarak yardım edebilecekleri alanlar hakkında farkındalık yaratmak için çalışmalar yapılabilir.

- Öğretmen adayları siber zorbalık üzerinde çalışan ve projeler üreten sivil toplum kuruluşlardan kendilerini bu konuda bilinçlendirmek için eğitimlere katılabilirler.

- Siber zorbalığa uğrayan kişilerin araştırma konusu olduğu ve farklı branşlarla birlikte çalışılarak detaylı bir akademik çalışma yapabilir.

\section{KAYNAKÇA}

Arıcak, O. T. (2011). Siber zorbalık: Gençlerimizi bekleyen yeni tehlike. Kariyer Penceresi, 6, $10-11$.

Arıcak, T., Siyahhan, S., Uzunhasanoğlu, A., Sarıbeyoğlu, S., Çıplak, S., Yılmaz, N., \& Memmedov, C. (2008). Cyberbullying among Turkish adolescents. Cyberpsycology and Behavior 11(3), 253-261.

Ayas, T. ve Horzum, M. (2014). Orta öğretim öğrencilerin psikolojik belirtilere göre sanal zorba ve sanal mağdur düzeylerinin yordanması. Journal of Technology Addiction and Cyberbullying, 1(2), 21-36.

Ayas, T. ve Horzum, M. B. (2011). Öğretmenlerin sanal zorbalık algılarının çeşitli değiş̧kenlere göre incelenmesi. International Online Journal of Educational Sciences, 3(2), 619-640.

Ayas, T. ve Pişkin, M. (2011). Lise öğrencileri arasındaki zorbalık olaylarının cinsiyet, sınıf, düzeyi ve okul türü bakımından incelenmesi. İlköğretim Online, 10(2), 550-568.

Bee, H. \& Boyd, D. (2009). Çocuk gelişim psikolojisi. İstanbul: Kaknüs yayınları.

Belsey, B. (2007). Cyberbullying: A real and growing threat. ATA Magazine, 88(1), 14-21.

Bhat, C. S. (2008). Cyberbullying: Overview and strategies for school counselors, guidance officers and all school personnel. Australian Journal of Guidance, 31(5), 112-121.

Boxer, P., \& Tisak, M. S. (2005). Children's beliefs about the continuity of aggression. Aggressive Behavior, 31, 172-188.

Bridge, B. (2010). Zorbalık-Mobbing Bilinmeyen Çeşitleri ve Çözümleri (2.Baskı). İstanbul: Beyaz Ayin.

Burnukara, P. (2009). Illk ve orta ergenlikte geleneksel ve sanal akran zorbalığına ilişkin betimsel bir inceleme. Yayımlanmamış yüksek lisans tezi, Hacettepe Üniversitesi, Eğitim Bilimleri Enstitüsü, Ankara.

Burnukara, P. ve Uçanok, Z. (2012). Okul ortamı ve sanal ortamda meydana gelen akran zorbalığı ne ölçüde örtüşüyor? Türk Psikoloji Dergisi, 27(69), 81-96. 
Büyüköztürk, Ş., Çakmak, E. K., Akgün, Ö. E., Karadeniz, Ş., \& Demirel, F. (2012). Bilimsel araştırma yöntemleri. Ankara: Pegem Akademi Yayınları.

Chapin, J. (2016). Adolescents and cyber bullying: The precaution adoption process model. Education and Information Technologies, 21(4), 719-728. doi:10.1007/s10639-014-9349-1

Cho, Y. K. \& Yoo, J. W. (2017). Cyberbullying, internet and SNS usage types, and perceived social support: a comparison of different age groups. Information, Communication $\mathcal{E}$ Society, 20(10), 1464-1481. DOI: 10.1080/1369118X.2016.1228998

Çal, Ü. T. (2019). Üstün zekalı ve yetenekli öğrencilerin çevreye yönelik görsel algılarının incelenmesi. Journal of Innovative Researh in Social Studies, 2(2), 135-148.

Çifçi, S. (2010). Dokuzuncu sını öğrencilerinin sanal zorbalık düzeyleri ile empatik eğilim düzeyleri arasındaki ilişki. Yayımlanmamış Yüksek Lisans Tezi. Gaziosmanpaşa Üniversitesi, Eğitim Bilimleri Enstitüsü, Tokat.

Demirkaya, H., \& Çakar, E. (2012). İlköğretim yedinci sınıf öğrencilerinin eleştirel düşünme becerilerinin değişkenlere göre incelenmesi. Ege Eğitim Dergisi, 13(2), 33-49.

Demirkaya, H., \& Ünal, O. (2018). Sosyal bilgiler öğretmen adaylarının kamu hizmeti motivasyonu algıları ve sosyal adalet idealleri. Turkish Studies, 13(4), 455-474. http://dx.doi.org/10.7827/TurkishStudies.13016

Dilmaç, B. (2009). Sanal zorbalığ1 yordayan psikolojik ihtiyaçlar: Lisans öğrencileri için bir ön çalışma. Kuram ve Uygulamalarda Ĕ̆itim Bilimleri, 9, 1291-1325.

Eroğlu, Y., \& Peker, A. (2015). Ergenlerde akran ilişkileri ile siber zorbalık statüleri arasındaki ilişkinin incelenmesi. Electronic Turkish Studies, 10(11), 593-606.

Freud, S. (2012). Dinin kökenleri. İstanbul: Payel Yayınları.

Hinduja, S., \& Patchin, J. W. (2009). Bullying beyond the schoolyard: Preventing and responding to cyberbullying. California: Carwin Pres.

Horzum, M. B. ve Ayas, T. (2014). Orta öğretim öğrencilerin psikolojik belirtilere göre sanal zorba ve sanal mağdur düzeylerinin yordanması. Online Journal of Technology Addiction and Cyberbullying, 1(2), 21-36.

Li, Q. (2007). Bullying in the new playground: Research into cyberbullying and cyber victimisation. Australasian Journal of Educational Technology, 23(4), 435- 454.

Merter, M. (2014). Nefs psikolojisi ve rüyaların dili. İstanbul: Kaknüs Yayınları.

Morin, H. K., Bradshaw, C. P., \& Kush, J. M. (2018). Adjustment outcomes of victims of cyberbullying: the role of personal and contextual factors. J. Sch. Psychol. 70, 74-88. doi: 10.1016/j.jsp.2018.07.002

Öztürk, A., \& Açıl, F. B. (2020). Sosyal bilgiler öğretmen adaylarının üst bilişsel farkındalıklarının bazı değişkenlere göre incelenmesi. Journal of Innovative Research in Social Studies, 3(1), 54-69.

Patchin, W., \& Sameer, J. H. (2006). Bullies move beyond the schoolyard: A preliminary look at cyberbullying. Youth Violence and Juvenile Justice, 4(2), 148-169. 
Peker, A., Eroğlu, Y., \& Çitemel, N. (2012). Boyun eğici davranışlarla siber zorbalık ve siber mağduriyet arasındaki ilişkide cinsiyetin aracılığının incelenmesi. Uluslararası İnsan Bilimleri Dergisi, 9(1), 205- 221.

Pişkin, M. (2002). Okul zorbalığı: Tanımı, türleri, ilişkili olduğu faktörler ve alınabilecek önlemler. Kuram ve Uygulamada Ĕ̆itim Bilimleri Dergisi, 2, 531-562.

Sayar, K. (2002). Aşınan kimlikler, dağılan kişilikler, benlik, kişilik ve kişilik bozuklukları üzerine kültürel bir okuma. Divan: Disiplinler arası Çalışmalar Dergisi, 13(2), 262-293.

Serin, H. (2012). Ergenlerde siber zorbalık / siber mağduriyet yaşantıları ve bu davranışlara ilişkin öğretmen ve eğitim yöneticilerinin görüşleri. Yayınlanmamıs Doktora Tezi. İstanbul Üniversitesi Sosyal Bilimler Enstitüsü, İstanbul.

Sleglova, V., \& Cerna, A. (2011). Cyberbullying in adolescent victims: Perception and coping. Cyberpsychology: Journal of Psychosocial Research on Cyberspace, 5(2), 1-16.

Slonje, R., \& Smith, P. K. (2008). Cyberbullying: Another main type of bullying? Scandinavian Journal of Psychology 49, 147-154.

Smith, K. P., Mahdavi, J., Carvalho, M., Fisher, S., Russel, S., \& Tippett, N. (2008). Cyberbullying: Its nature and impact in secondary school pupils. Journal of Child Psychology and Psychiatry, 49(4), 376-385.

Taçyıldız, Ö. (2010). Lise öğrencilerinin internet bağımlılı̆̆ı düzeylerinin bazı değişkenlere göre yordanması, Yayınlanmamış Yüksek Lisans Tezi, Ege Üniversitesi, Eğitim Bilimleri Enstitüsü, İzmir.

Tamer, N., \& Vatanartıran, S. (2014). Ergenlerin teknolojik zorbalık algıları. Online Journal of Technology Addiction \& Cyberbullying, 41(1), 41-59.

Tanrıkulu, T., Kınay, H. ve Arıcak, O. (2013). Siber zorbalığa ilişkin duyarlılık ölçeği: Geçerlik ve güvenirlik çalışması. Trakya Üniversitesi Ĕ̆itim Fakültesi Dergisi, 3(1), 38-47.

Topkaya, Y., Tangülü, Z., Yılar, B., \& Şimşek, U. (2015). Social studies pre-service teachers'computer self efficacy beliefs and attitudes on computer-assisted instruction. Journal of International Social Research, 8(36), 742-748.

Williams, K. R., \& Guerra, N. G. (2007) Prevelance and predictors of internet bullying. Journal of Adolescent Health, 41, 14-21.

Yaman, E. \& Peker, A. (2012). Ergenlerin siber zorbalık ve siber mağduriyete ilişkin algıları. Gaziantep Üniversitesi Sosyal Bilimler Dergisi, 11(3), 819-833.

Yaman, E., Eroğlu, Y., \& Peker, A. (2011). Okul zorbalığı ve siber zorbalık. İstanbul: Kaktüs Yayınları.

Yılmaz, E., Şahin, Y., Haseski, H., \& Erol, O. (2014). Lise öğrencilerinin internet bağımlılık düzeylerinin çeşitli değişkenlere göre incelenmesi: Balıkesir ili örneği. Eğitim Bilimleri Araştırmaları Dergisi, 4(1), 133-144.

Yurdakul, I. K. (2013). Evren ve Örneklem. A. A. Kurt içinde, Bilimsel Araştırma Yöntemleri (s. 75-91). Ankara: Anadolu Üniversitesi Açıöğretim Yayınları. 